\title{
KNOWLEDGE MANAGEMENT, THE PREMISE FOR OPTIMAL SOLUTIONS OF COMMON PROBLEMS: IMPLEMENTATIONS AND PROPOSALS FOR A SUCCESSFUL COMPANY
}

\author{
Manole VELICANU \\ Daniela LIȚAN \\ Larisa COPCEA (TEOHARI) \\ Mihai TEOHARI \\ Mirela STEREA \\ Anca APOSTU \\ Professor, $\mathrm{PhD}$, Economic Informatics and Cybernetics Department \\ Academy of Economic Studies, Bucharest, Romania \\ manole.velicanu@ie.ase.ro \\ PhD candidates, Economic Informatics and Cybernetics Department \\ Academy of Economic Studies, Bucharest, Romania \\ litan_daniela@yahoo.com, larisa.copcea@yahoo.com,mteohari@yahoo.com, \\ sterea_mirela@yahoo.com, ancaiapostu@gmail.com
}

\begin{abstract}
One of the challenges of the post-dot-com bubble era that many organizations are facing is being asked to deliver more with little or no budget increase in order to improve the bottom line. In addition, in the wake of the recent corporate accounting scandals, new regulations have been put into place to enhance corporate responsibility, improve financial disclosures and combat corporate accounting fraud. Taking into account all these challenges and problems, a possible 'answer' analyzed in this paper is, on the one hand, the concept of integrated Knowledge Management with classical/traditional information technologies (the Virtual Business Platform - VBP), specific to this concept and on the other hand, the analysis and forecasts methods (predictive markets) and technologies currently encountered in more 'remote' Knowledge Management areas (data warehouse, Business Intelligence, data mining etc.).
\end{abstract}

Keywords: Knowledge Management, information technologies, data warehouse, Business Intelligence, Siebel, predictive markets. 